\begin{tabular}{|c|c|}
\hline 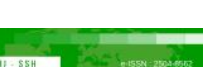 & Malaysian Journal of Social Sciences and Humanities (MJSSH) \\
\hline Malaysian Journal of & Volume 6, Issue 3, March 2021 \\
\hline (Mu-ssH) & e-ISSN : 2504-8562 \\
\hline & $\begin{array}{l}\text { Journal home page: } \\
\text { www.msocialsciences.com }\end{array}$ \\
\hline
\end{tabular}

\title{
Hubungan Kepemimpinan Instruksional Pengetua dengan Sikap Guru Terhadap Perubahan dalam Pendidikan Abad Ke-21
}

\author{
Mejran Duman', Muhamad Suhaimi Taat' ${ }^{1}$,Mohd Khairuddin Abdullah'1 \\ ${ }^{1}$ Fakulti Psikologi dan Pendidikan, Universiti Malaysia Sabah (UMS) \\ Correspondence: Mejran Duman (mejran7781@gmail.com)
}

\begin{abstract}
Abstrak
Kajian ini dilakukan bertujuan untuk mengenal pasti hubungan kepemimpinan instruksional pengetua dengan sikap guru terhadap perubahan dalam pendidikan abad ke-21 dalam kalangan guru sekolah menengah harian biasa bantuan penuh kerajaan di negeri Sabah, Malaysia. Kajian bukan eksperimental ini mengaplikasikan kaedah tinjauan dengan menggabungkan beberapa teknik pensampelan kebarangkalian bagi mendapatkan sampel. Data dikumpulkan menggunakan satu set borang soal selidik adaptasi yang di tadbir ke atas 440 orang guru. Data dianalisis menggunakan perisian IBM SPSS Statistics 26.0. Statistik deskriptif dan inferensi seperti peratus, min, sisihan piawai, Ujian-t, dan korelasi Pearson digunakan untuk menganalisis data bagi menjawab soalan kajian. Analisis deskriptif menunjukkan kepemimpinan instruksional pengetua dan sikap guru terhadap perubahan pendidikan abad ke-21 diamalkan pada tahap yang tinggi. Hasil kajian mendapati tidak terdapat perbezaan skor min yang signifikan kepemimpinan instruksional pengetua berdasarkan jantina. Namun terdapat perbezaan skor min yang signifikan sikap guru terhadap perubahan dalam pendidikan abad ke-21 berdasarkan jantina. Ujian korelasi Pearson pula menunjukkan terdapat hubungan linear positif yang sederhana bagi kepemimpinan instruksional pengetua dengan sikap guru terhadap perubahan pendidikan abad ke-21. Implikasi dan cadangan kajian lanjut turut dibincangkan.
\end{abstract}

Kata kunci: sikap guru terhadap perubahan dalam pendidikan, kepemimpinan instruksional pengetua, abad ke-21

\section{The Relationship of Principal Instructional Leadership with Teachers' Attitudes towards Change in 21st Century Education Abstract}

This study was aimed at identifying the relationship of Principal Instructional Leadership with Teachers' Attitudes Towards Change in 21st Century Education among teachers in normal daily government-aided secondary schools in Sabah, Malaysia. The non-experimental study utilised the observation method by combining several variable sampling techniques to obtain a sample. Data was collected through a set of adapted questionnaires administered to 440 teachers. The data were analyzed using IBM SPSS Statistics 26.0 software. Descriptive and inferential statistics such as percentage, mean, standard deviation, t-test, and Pearson correlation were used to analyze the data to answer the research questions. Descriptive analysis Principal Instructional Leadership and Teachers' Attitudes Towards Change 21st Century Educational being practised at a high level. Findings of the study found that there was no significant difference in the mean score of Instructional Leadership based on gender, but the study found that there was a significant difference in mean score of Teachers' Attitudes Towards Change in 21st Century Education based on gender. Pearson correlation test indicated a 
moderate positive linear relationship for Principal Instructional Leadership with Teachers' Attitudes Towards Change 21st Century Educational. The implications and suggestions for further study are also discussed.

Keywords: teachers' attitudes toward changes in education, principal instructional leadership, 21st century

\section{Pengenalan}

Perkembangan dunia pendidikan pada masa kini menuntut pelbagai keperluan ilmu dan pemerkasaan sistem pengurusan. Namun demikian, dalam abad ke-21 ini negara menghadapi banyak halangan dari segi perubahan sikap guru yang bukanlah satu hal yang mudah untuk dilaksanakan. Perubahanperubahan tersebut menuntut banyak komitmen dan perubahan cara berfikir serta cara bekerja para warganya (Koh Lee Chin, 2014). Pengaplikasian pengetahuan seseorang pemimpin dalam bidang pengurusan pendidikan tidak akan berlaku jika tanpa memberikan sumbangan ke arah perubahan sikap guru. Sikap positif untuk perubahan didapati penting dalam mencapai matlamat organisasi dan dalam menggantikan program perubahan (Eby et al., 2000; Ab Khalid, Ahmad \& Hamdan 2015; Abdul Aziz, 2015).

Kementerian Pendidikan Malaysia (KPM) turut melaksanakan kajian semula terhadap sistem pendidikan negara dalam konteks standard pendidikan antarabangsa dan akhirnya, Pelan Pembangunan Pendidikan Malaysia (PPPM) 2013-2025 dilancarkan (KPM, 2013). Pembangunan pendidikan negara adalah untuk mencapai kualiti dan juga kecemerlangan pendidikan di samping pembangunan fizikal institusi pendidikan itu sendiri (Tem Na, 2013). Justeru kajian berkenaan sikap guru terhadap perubahan dalam melaksanakan tugasan hakiki mereka dapat menjawab dan menyelesaikan permasalahan yang berlaku dalam pendidikan pada masa kini secara lebih optimum dan bersifat menyeluruh.

Guru memainkan peranan penting dalam memastikan pencapaian di sesuatu institusi pendidikan (Bai, Piri \& Piri, 2014). Manakala menurut Nurharani Selamat, Nur Zahira Samsu dan Nur Shaminah Mostafa Kamalu (2013) peranan guru adalah sangat penting dalam membentuk masa depan negara. Kajian-kajian yang ketara dalam pengurusan perubahan telah mendapati bahawa faktor penting yang mempengaruhi kejayaan atau kegagalan sebarang perubahan adalah penentangan individu terhadap perubahan yang berkait rapat dengan sikap positif atau negatif untuk berubah (Aslan, Beycioglu \& Konan, 2008; Bouckenooghe, 2009). Sukor Rahmad et al. (2016), menyatakan bahawa majoriti guru sekolah rendah dan menengah didapati tidak mempunyai kemahiran berfikir kreatif dan banyak yang tidak jelas dalam menjalankan pedagogi kreatif di sekolah.

Kementerian pendidikan Malaysia mendapati 50\% pengajaran guru disampaikan pada tahap tidak memuaskan (PPPM 2013-2025). Pendidikan abad ke-21 mendidik guru untuk lebih matang dalam mengaplikasi teknik pengajaran dan pelajar akan mendapat manfaat dari sesi pembelajaran untuk menghasilkan serta mengekalkan kemahiran yang diperlukan bagi menghadapi cabaran era globalisasi (Amran \& Rosli, 2017). Guru adalah aset yang penting dalam membangunkan negara (Erdamar \& Demirel, 2016). Tanpa adanya perubahan sikap maka semua perancangan dan perlaksanaan dalam pendidikan hanyalah angan-angan sahaja dan tidak dapat direalisasikan realiti yang ingin dicapai.

Sikap individu adalah peramal yang baik untuk kesediaan perubahan dalam mana-mana organisasi (Hayes, 2010; Nilakant \& Ramanarayan, 2006). Ia dianggap sebagai satu penentu utama keinginan seseorang untuk melakukan tingkah laku untuk menyokong atau menentang perubahan itu. Sikap positif terhadap perubahan boleh menyebabkan niat tingkah laku positif dan tingkah laku seterusnya seperti terlibat secara aktif dalam perubahan (Oreg, 2003) atau sangat komited untuk berubah (Spreitzer \& Mishra, 2002). Sikap positif untuk perubahan didapati penting dalam mencapai matlamat organisasi dan dalam menggantikan program perubahan (Bareil, Savoie, \& Meunier, 2007; Bernerth, 2004; Eby, Adams, Russel, \& Gaby, 2000). Di sekolah, sikap positif merupakan petunjuk penting 
dalam mengadaptasi inovasi (Thomas \& Sufi Mary, 2003). Sikap guru terhadap perubahan itu adalah penentu utama sama ada individu menginginkan atau menentang perubahan (Anghelachea \& Bentea 2012).

Dalam dunia pendidikan, kepimpinan memainkan peranan penting sebagai perangsang kepada kemajuan sistem pendidikan khususnya dalam perubahan organisasi (Parris \& Peachey, 2013; Mei Kin, Abdull Kareem, Nordin, \& Wai Bing, 2017). Peringkat sekolah, kepimpinan pengetua didapati memainkan peranan penting pada tingkah laku organisasinya (Fullan, 2011; Nuinda Alias \& Khadijah Daud, 2014; Ahmad \& Ghavifekr, 2014). Oleh itu, dalam usaha menggerakkan guru menghadapi setiap perubahan dalam organisasi, pengetua perlu mempraktikkan amalan kepimpinan terbaik (Ibrahim \& Don, 2014).

Tanggungjawab bagi mewujudkan iklim organisasi sekolah yang positif bermula dengan pemimpin atau pengurus sekolah, yang menyediakan kepimpinan dalam membangunkan dan mengekalkan iklim yang kondusif untuk pembelajaran (Jeswani \& Dave, 2012). Pelbagai penyelidikan telah dijalankan bagi mengenal pasti gaya kepimpinan yang berupaya dapat mengubah sikap dan tingkah laku seseorang serta berjaya membuat perubahan-perubahan besar (Ishak, 2002). Kajian menunjukkan wujudnya, banyak kelemahan dalam kepimpinan pengetua sehingga menyebabkan penolakan dalam kalangan guru kerana kurang bersedia (Goksoy, 2012; Ozdemir et al., 2016). Isu berkaitan pengetahuan tentang gaya kepimpinan memerlukan seseorang pemimpin untuk lebih yakin dan berkemahiran sebagai pengurus, pentadbir dan pemimpin serta pendekatan memberi arah, melaksanakan rancangan, dan memotivasi orang (Northouse, 2015).

Guru-guru memerlukan sokongan, motivasi dan komunikasi yang tinggi yang ditunjukkan oleh pemimpin sekolah (Mohammad Sulaiman, 2012; Chaudhry et al. 2012; Joo et al. 2012). Kejayaan, keberkesanan, atau kegagalan perubahan sekolah adalah dikaitkan dengan kepimpinan pengetua (Ainscow, Beresford, Harris, Hopkins, Southworth, \& West, 2012; Kotter \& Cohen, 2012; Ahmad, Salleh, Awang, \& Mohamad, 2013; Ghitulescu, 2013; Nuinda Alias \& Khadijah Daud, 2014; Anthony, Said, Mohamad, \& Mokhtar, 2015). Hal ini demikian kerana perubahan tidak akan berkesan dalam organisasi pendidikan kecuali pengetua sendiri melalui kepimpinannya, memulakan secara kompetitif (Sentočnik, Sales, \& Richardson, 2016). Misalnya kurangnya peluang untuk maju, kurangnya dorongan dan pengiktirafan, tekanan, persekitaran kerja yang tidak menyokong, dan kurangnya keseimbangan kerja-kehidupan (Sahito \& Vaisanen, 2017).

Di samping itu banyak bukti menunjukkan sokongan kepimpinan gagal diperoleh berkaitan soal kebajikan dan keperluan kakitangan bawahan untuk dihargai, dibangun dan dipimpin (English, 2011; Apak, Taat, Talip, \& Kiflee, (2019). Kajian juga mendapati kepimpinan pengetua bersifat negatif terhadap kepentingan perubahan dan pelbagai alasan diberi untuk menolak keperluan teknologi yang mendesak dalam kalangan guru (Msila, 2015). Kajian (Hick, 2012; Manning \& Bucher, 2013) yang mencatatkan bahawa pemimpin tidak memiliki pengetahuan pengurusan organisasi akan berhadapan dengan masalah kesukaran memberikan arahan kepada guru semasa pengajaran.

\section{Tujuan dan Objektif kajian}

Kajian ini bertujuan untuk mengenal pasti hubungan antara kepemimpinan intruksional pengetua dengan sikap guru terhadap perubahan dalam pendidikan abad ke-21. Objektif kajian ini adalah untuk:

i. Mengenal pasti tahap kepemimpinan instruksional pengetua dan sikap guru terhadap perubahan dalam pendidikan abad ke-21.

ii. Mengenal pasti perbezaan skor min kepemimpinan instruksional pengetua dan sikap guru terhadap perubahan dalam pendidikan abad ke-21 berdasarkan jantina.

iii. Mengenal pasti hubungan yang signifikan kepemimpinan instruksional pengetua dengan sikap guru terhadap perubahan dalam pendidikan abad ke-21. 


\section{Hipotesis Kajian}

Berpandukan objektif kajian yang telah ditetapkan, beberapa hipotesis nul telah dibina. Kajian ini menggunakan aras hipotesis nul berikut:

$\mathrm{Ho}^{1}$ Tidak terdapat perbezaan skor min yang signifikan kepemimpinan instruksional pengetua berdasarkan jantina.

$\mathrm{Ho}^{2}$ Tidak terdapat perbezaan skor min yang signifikan sikap guru terhadap perubahan dalam pendidikan abad ke-21 berdasarkan jantina.

$\mathrm{Ho}^{3}$ Tidak terdapat hubungan yang signifikan kepemimpinan instruksional pengetua dengan sikap guru terhadap perubahan dalam pendidikan abad ke-21.

\section{Tinjauan Literatur}

\section{Sikap Guru Terhadap Perubahan dalam Pendidikan Abad Ke-21}

Sikap guru terhadap perubahan dalam pendidikan abad ke-21 ini menunjukkan tahapnya berapa banyak sokongan individu terhadap perubahan yang berlaku dalam organisasi (Robbins, 1996). Kajian untuk mengenal pasti sikap guru terhadap perubahan adalah signifikan kerana ia adalah salah satu matlamat dalam reformasi sekolah dan negara iaitu meningkatkan pencapaian akademik murid-murid (KPM, 2013). Sikap ditakrifkan sebagai tindak balas kecenderungan yang konsisten dan rapi terhadap rangsangan dengan cara yang baik atau tidak baik (Tai \& Omar, 2016).

Menurut Kalafatihan et al. (1999) dan De Clercq et al. (2013), sikap seseorang individu mempunyai hubungan yang kuat terhadap hasil keinginan seseorang individu dengan menilai sejauh mana kepentingan hasil tersebut kepada individu tersebut (Mohar et al., 2007). Dalam keadaan ini, sikap menjadi satu elemen yang penting dalam mengambil kira persoalan-persoalan yang timbul demi mencapai keinginan individu tersebut (Mohd Noor \& Mohammad Basir 2009). Sebaliknya, sikap ditakrifkan sebagai kecenderungan yang dipelajari untuk bertindak balas terhadap sesuatu objek secara konsisten atau tidak sesuai (Fishbein \& Ajzen, 2010).

Menurut Tai (2013), sikap guru terhadap perubahan (SGTP) adalah keadaan dalaman yang mempengaruhi pilihan guru terhadap pilihan peribadi guru atau kecenderungan tindak balas terhadap perubahan. Beberapa kajian berkaitan sikap guru terhadap perubahan dalam pendidikan abad ke-21 telah dilakukan. Kajian Brenner (2013) mendapati tidak terdapat perbezaan yang signifikan antara perbezaan kumpulan antara keberkesanan guru dengan jantina atau sikap terhadap perubahan dan jantina. Seterusnya Brenner (2013) juga turut mendapati bahawa tidak terdapat perbezaan yang signifikan antara perbezaan kumpulan umur. Kajian Adil (2016) turut menunjukkan komponen kesediaan perubahan mempunyai kesan berbeza terhadap komitmen perubahan berdasarkan pengalaman mengajar. Kajian Noriati et al. (2010) membawa kepada hubungan yang kuat antara aspek kognitif dengan tingkah laku, aspek kognitif dengan afektif dan aspek tingkah laku dengan afektif kerana hasil analisis dapatan kajian telah membuktikan bahawa semua guru hanya mempunyai tahap kesediaan yang sederhana sahaja secara keseluruhannya dalam ketiga-tiga aspek yang dikaji.

\section{Kepemimpinan Instruksional Pengetua}

Kepemimpinan instruksional dalam konteks kajian ini adalah merujuk kepada tindakan, pengaruh dan kepakaran pengetua yang mendorong kepada proses menetapkan misi dan matlamat sekolah, mengurus program pengajaran dan menggalakkan iklim sekolah yang positif (Hallinger, 2000). Yukl (2008) merujuk kepada sekumpulan manusia yang berinteraksi, berhubung dan mempengaruhi satu sama lain dalam menuju objektif. Abdul Ghani (2011) sebagai pemimpin instruksional, pengetua memainkan peranan sebagai pembimbing, penyelia, penilai dan pembekal sumber bagi menggalakkan dan memperbaiki pengajaran dan pembelajaran $(\mathrm{P} \& \mathrm{P})$ di sekolah. 
kajian ini adalah berdasarkan model kepemimpinan instruksional yang telah diutarakan oleh Hallinger dan Murphy (1985) yang seterusnya dijadikan asas dalam pembinaan kerangka teori kajian ini. Model ini berjaya menerangkan berkaitan tugas dan tingkah laku yang perlu dilaksanakan oleh seseorang pengetua sebagai pemimpin instruksional bermula dari menetapkan matlamat sekolah, mengurus program pengajaran dan pembelajaran dalam bilik darjah sehinggalah kepada keadaan iklim sekolah yang boleh menyumbang kepada kejayaan pencapaian pelajar.

Seterusnya Kursunoglu dan Tanriogen (2009) dalam kajian mereka turut melaporkan bahawa tingkah laku kepemimpinan instruksional pengetua seperti yang dirasakan oleh guru adalah peramal penting pada sikap guru terhadap perubahan dan terdapat hubungan positif yang signifikan antara sikap tingkah laku guru terhadap perubahan. Juita, (2012) dalam kajiannya yang mengkaji kepimpinan instruksional pengetua dan komitmen guru terdapat hubungan yang signifikan antara kepimpinan Instruksional dengan komitmen guru. Mohd Ibrahim, Mohammed Sani dan Rosemawati (2015) telah menjalankan kajiannya mengenai kompetensi kepemimpinan instruksional di kalangan pengetua. Lee dan Shukri (2016) dalam kajian mereka terhadap guru sekolah menengah menunjukkan tahap kepimpinan instruksional, efikasi dan tugas rutin pengetua adalah tinggi.

\section{Kerangka Konseptual Kajian}

Dalam kajian ini, sikap guru terhadap perubahan dalam pendidikan abad ke-21 ditetapkan sebagai pemboleh ubah bersandar, manakala kepemimpinan instruksional pengetua bertindak sebagai pemboleh ubah bebas kajian. Rajah 1 menunjukkan kerangka konseptual mengenai hubungan antara pemboleh ubah dalam kajian ini.

Rajah 1: Kerangka Konseptual Kajian

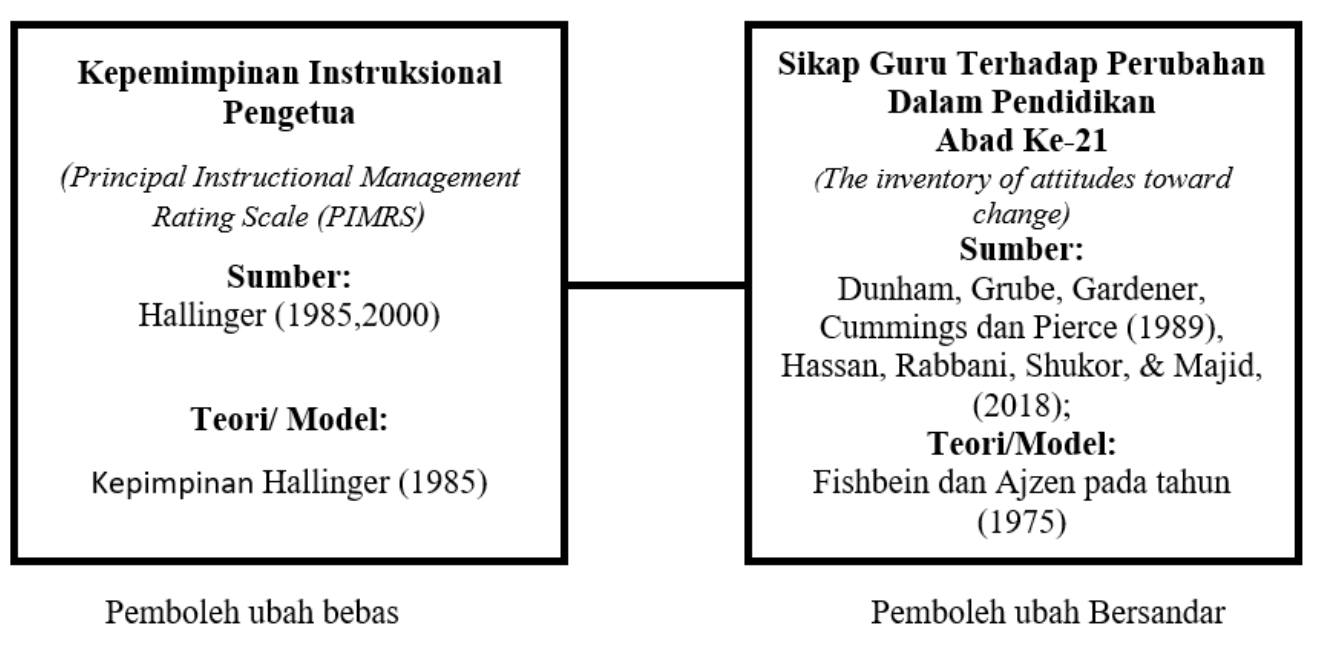

\section{Metod Kajian}

Reka bentuk kajian ini adalah bukan eksperimental. Kajian ini menggunakan kaedah tinjauan sampel, yang bertujuan mengumpul maklumat daripada sebahagian populasi berkaitan pemboleh ubah kajian. Pendekatan kuantitatif digunakan bagi memudahkan usaha memperoleh data, di samping memastikan kebolehpercayaan, kesahihan dan kebolehperihalan data yang diperoleh. Penyelidikan yang melibatkan analisis statistik deskriptif dan inferensi ini turut mengkaji perbandingan persepsi guru dari aspek demografi iaitu jantina terhadap pemboleh ubah kepemimpinan instruksional pengetua dan sikap guru terhadap perubahan dalam pendidikan abad ke-21.

Dalam kajian ini, populasi adalah dirujuk khusus kepada guru sekolah menengah harian biasa yang menerima bantuan penuh kerajaan di negeri Sabah. Terdapat 200 buah sekolah menengah kategori 
harian biasa bantuan penuh kerajaan dengan seramai 14,909 orang guru sedang berkhidmat (Jabatan Pendidikan Negeri Sabah, 2018). Penyelidik menetapkan saranan Krejcie \& Morgan (1970) dijadikan panduan umum dalam menetapkan saiz sampel minimum kajian ini. Berdasarkan penelitian dan mengambil kira prinsip-prinsip asas statistik yang perlu dipatuhi untuk melaksanakan analisis data, penyelidik menetapkan saiz sampel untuk kajian ini adalah sebanyak 440 orang. Dalam kajian ini, beberapa kaedah pensampelan kebarangkalian digunakan seperti kaedah pensampelan berstrata, pensampelan kluster tahap pertama dan kedua, dan akhir sekali pensampelan rawak mudah. Berdasarkan penggabungan beberapa kaedah pensampelan, akhirnya jumlah sampel yang disasarkan dalam kajian ini ditetapkan memandangkan lokasi negeri Sabah yang luas dan memiliki kepelbagaian ciri.

Borang soal selidik merupakan instrumen utama dalam kajian ini. Penggunaan borang soal selidik adalah sesuai digunakan untuk mendapatkan data terutamanya kajian berbentuk kuantitatif yang memerlukan saiz sampel besar dan menyeluruh (Jacob \& Ary, 1990; Babbie, 2001; Mohd. Majid Konting, 2000; Chua, 2006). Skala pengukuran yang digunakan dalam kajian ini ialah skala Likert lima mata. Alat kajian yang digunakan untuk mengukur pemboleh ubah bebas kajian ini ialah Principal Instructional Management Rating Scale (PIMRS) yang telah dibangunkan Hallinger (1985). Beberapa penyelidik terdahulu seperti (Shafinaz Maulod, 2017; Usang anak Ngrabang, 2012; Baharom, 2004; Andi Audryanah Md. Noor, 2007; Davarajoo, 2012; Lokman et al., 2012; Suzanna, 2015) telah menggunakan alat pengukur ini.

Manakala, bagi mengukur pemboleh ubah bersandar kajian ini "The inventory of attitudes toward change” oleh Dunham, Grube, Gardener, Cummings dan Pierce (1989) telah digunakan. TATC diguna pakai kerana ia merupakan instrumen yang digunakan secara meluas dalam mengukur sikap guru terhadap perubahan. Soal selidik TATC oleh Dunham, Grube, Gardener, Cummings dan Pierce (1989) telah diguna pakai oleh beberapa penyelidik terdahulu seperti Kursunoglu dan Tanriogen (2009); Vakola (2004); dan Yousef (2000), Buck (2009) serta Jamelaa dan Jainabee (2011); Kin \& Kareem (2017). Semua instrumen telah melalui penyemakan kesahan kandungan terlebih dahulu sebelum digunakan ke atas sampel sebenar.

\section{Dapatan Kajian}

Berdasarkan analisis deskriptif terhadap pemboleh ubah jantina, didapati sebanyak 121 orang (27.5\%) adalah responden lelaki, manakala selebihnya 319 orang (72.5\%) merupakan responden perempuan. Dapatan kajian juga menunjukkan skor min responden lelaki dan perempuan adalah pada tahap tinggi bagi setiap pemboleh ubah. Secara bandingan, skor min responden perempuan adalah lebih tinggi sedikit berbanding skor min responden lelaki bagi kedua-dua pemboleh ubah. Umumnya, analisis menunjukkan responden lelaki dan perempuan mempunyai tahap yang tinggi sama ada dalam persetujuan dan kekerapan mempersepsikan kepemimpinan instruksional pengetua dan pelaksanaan sikap guru terhadap perubahan dalam pendidikan abad ke-21 seperti yang ditunjukkan dalam Jadual 1.

Jadual 1: Skor Min Pemboleh Ubah Kajian Mengikut Jantina

\begin{tabular}{llll}
\hline Jantina & & KIP & SGTP21 \\
\hline \multirow{2}{*}{ Lelaki } & Min & 4.040 & 4.160 \\
& SP & 0.484 & 0.404 \\
\multirow{2}{*}{ Perempuan } & $N$ & 121 & 121 \\
& Min & 4.111 & 4.011 \\
\multirow{2}{*}{ Jumlah } & SP & 0.458 & 0.375 \\
& $N$ & 319 & 319 \\
KIP - Kepemimpinan Instruksional Pengetua & 4.052 \\
SGTP21 - Sikap Guru Terhadap Perubahan dalam pendidikan Abad Ke-21 \\
\hline \multicolumn{4}{l}{} \\
\hline
\end{tabular}




\section{Tahap Kepemimpinan Instruksional Pengetua dan Sikap Guru Terhadap Perubahan Dalam Pendidikan Abad Ke-21}

Analisis deskriptif iaitu kekerapan, peratusan, dan min digunakan untuk menentukan tahap pelaksanaan kepemimpinan instruksional pengetua dan sikap guru terhadap perubahan dalam pendidikan abad ke-21. Tahap pelaksanaan adalah berdasarkan panduan yang diberikan oleh skala Lokman dan M. Al-Muzammil (2008). Tahap pelaksanaan dilaporkan berdasarkan skor min yang diperolehi. Keputusan analisis skor min ditunjukkan dalam Jadual 2. Hasil analisis menunjukkan kedua-dua pemboleh ubah diamalkan pada tahap tinggi iaitu skor min bagi kepemimpinan instruksional pengetua $(\mathrm{M}=4.092, \mathrm{SP}=0.466$ dan skor min sikap guru terhadap perubahan dalam pendidikan abad ke-21 ( $\mathrm{M}=4.052, \mathrm{SP}=0.388)$ seperti yang dipaparkan dalam Jadual 2.

Jadual 2: Tahap Kepemimpinan Instruksional Pengetua dan Sikap Guru Terhadap Perubahan Dalam Pendidikan Abad Ke-21

\begin{tabular}{llll}
\hline Variabel & $\boldsymbol{N}$ & Min & SP \\
\hline Kepemimpinan Instruksional Pengetua & 440 & 4.092 & .466 \\
Sikap Guru Terhadap Perubahan Pendidikan & 440 & 4.052 & .388 \\
Dalam Abad Ke-21 & & & \\
\hline
\end{tabular}

\section{Ho $^{1}$ Tidak terdapat perbezaan skor min yang signifikan kepemimpinan instruksional pengetua berdasarkan jantina}

Keputusan ujian ditunjukkan dalam jadual 3 yang memaparkan hasil analisis deskriptif perbandingan skor min responden lelaki dan perempuan. Bagi sampel kajian ini $(N=440)$, terbukti bahawa terdapat perbezaan skor min yang sangat kecil $(\mathrm{M}=0.018)$ terhadap kepemimpinan instruksional Pengetua. Analisis menunjukkan min responden lelaki $(\mathrm{M}=4.040, \mathrm{SP}=0.484, N=121)$ lebih rendah berbanding min perempuan $(\mathrm{M}=4.111, \mathrm{SP}=0.458, N=319)$. Nilai min yang lebih tinggi bagi kumpulan responden perempuan menunjukkan persepsi mereka lebih tinggi terhadap amalan kepemimpinan instruksional Pengetua. Berdasarkan jadual 3, keputusan ujian- $t$ yang diperoleh adalah tidak signifikan $(t=-1.424$, $d f=438, p>0.05$ ). Oleh itu, Hipotesis nul 1 (Ho1) gagal ditolak. Justeru, dapatan ini menunjukkan bahawa tidak terdapat perbezaan bagi variabel kepemimpinan instruksional pengetua antara guru lelaki dan perempuan.

Jadual 3: Analisis Ujian- $t$ Kepemimpinan instruksional pengetua

Berdasarkan Jantina

\begin{tabular}{lcccccc}
\hline Variabel & M & SP & $\boldsymbol{F}$ & Nilai- $t$ & $\boldsymbol{d f}$ & $\begin{array}{l}\text { Sig } \\
\text { (2- } \\
\text { Hujung) }\end{array}$ \\
\hline KIP Lelaki & $\begin{array}{l}4.040 \\
\text { Perempuan }\end{array}$ & $\begin{array}{l}0.484 \\
0.458\end{array}$ & .012 & -1.424 & 438 & .912 \\
*Signifikan pada tahap $p<0.05$ & $\begin{array}{c}\text { (2-Hujung) } \\
\text { KIP - Kepemimpinan Instruksional Pengetua }\end{array}$ \\
\hline
\end{tabular}

\section{Ho$^{2}$ Tidak terdapat perbezaan skor min yang signifikan sikap guru terhadap perubahan dalam pendidikan abad ke-21 berdasarkanjantina}

Analisis bagi sampel kajian ini $(N=440)$ menunjukkan terdapat perbezaan min yang besar sebanyak $(\mathrm{M}=0.149)$ antara kedua-dua kumpulan responden dalam variabel sikap guru terhadap perubahan dalam pendidikan abad ke-21. Analisis yang dilakukan menunjukkan min responden lelaki $(\mathrm{M}=4.160$, $\mathrm{SP}=0.404, N=121)$ lebih tinggi berbanding min responden perempuan $(\mathrm{M}=4.011, \mathrm{SP}=0.375, N=319)$. Perkara ini membuktikan bahawa responden lelaki mempersepsikan sikap guru terhadap perubahan dalam pendidikan abad ke-21 lebih baik berbanding responden perempuan. Berdasarkan Jadual 4 keputusan yang diperoleh bagi sampel kajian ini $(N=440)$ adalah signifikan $(t=3.645, d f=438, p<0.05)$. Hal ini bermakna hipotesis nul $2\left(\mathrm{Ho}^{2}\right)$ adalah ditolak. Oleh itu, dapatan ini menunjukkan bahawa 
terdapat perbezaan bagi variabel sikap guru terhadap perubahan dalam pendidikan abad ke -21 antara guru lelaki dan perempuan.

Jadual 4: Analisis Ujian- $t$ Sikap Guru Terhadap Perubahan Dalam Pendidikan Abad Ke-21

Berdasarkan Jantina

\begin{tabular}{|c|c|c|c|c|c|c|c|}
\hline Variabel & & M & SP & $F$ & Nilai- $t$ & $d f$ & $\begin{array}{l}\text { Sig } \\
\text { (2-Hujung) }\end{array}$ \\
\hline SGTP21 & $\begin{array}{l}\text { Lelaki } \\
\text { Perempuan }\end{array}$ & $\begin{array}{l}4.160 \\
4.011\end{array}$ & $\begin{array}{l}0.404 \\
0.375\end{array}$ & 7.045 & 3.645 & 438 & .008 \\
\hline
\end{tabular}

\section{$\mathrm{Ho}^{3}$ Tidak terdapat hubungan yang signifikan kepemimpinan instruksional pengetua dengan sikapguru terhadap perubahan dalam pendidikan abad ke-21}

Keputusan nilai koefisien ujian korelasi Pearson bagi jumlah sampel kajian $(N=440)$ seperti yang ditunjukkan dalam Jadual 5 membuktikan wujudnya hubungan positif yang signifikan antara kepemimpinan instruksional pengetua $(r=0.359, p<0.01)$, dengan sikap guru terhadap perubahan dalam pendidikan abad ke-21. Walau bagaimanapun kekuatan hubungan didapati lemah bagi variabel kepemimpinan instruksional pengetua berpandukan indeks korelasi yang dicadangkan Cohen et al. (2007) dengan sikap guru terhadap perubahan dalam pendidikan abad ke-21. Memandangkan dapatan menunjukkan hubungan yang signifikan antara kedua-dua variabel kajian, maka hipotesis nul $3\left(\mathrm{Ho}^{3}\right)$ ditolak. Justeru, dapatan kajian menunjukkan bahawa terdapat hubungan variabel kepemimpinan instruksional pengetua dengan sikap guru terhadap perubahan dalam pendidikan abad ke-21.

Jadual 5: Analisis Korelasi Pearson kepemimpinan instruksional pengetua dengan sikap guru terhadap perubahan dalam pendidikan abad ke-21

\begin{tabular}{lll}
\hline & \multicolumn{1}{c}{ KIP } \\
\hline SGTP21 & Korelasi Pearson & $.359 * *$ \\
$* *$ Sign & .000 \\
KIP $=$ Kepemimpinan Instruksional Pengetua & \\
SGTP21 = Sikap Guru Terhadap Perubahan Dalam Pendidikan Abad Ke-21
\end{tabular}

\section{Perbincangan Dapatan Kajian}

Berdasarkan analisis deskriptif yang dilakukan, kepemimpinan instruksional pengetua dalam kalangan guru didapati berada pada tahap tinggi. Keadaan ini menepati hasrat KPM (2013) yang memandang serius penekanan unsur kepimpinan dalam organisasi seperti yang dijelaskan melalui PPPM 20132025. Pernyataan ini sejajar dengan penjelasan yang diberikan oleh Engelhart (2012) tentang perkongsian kepimpinan dalam mewujudkan iklim sekolah yang positif. Kajian ini selari dengan kajian oleh Simin et al., (2015), Jameela (2012), dan Shafinaz Maulod (2017) juga memperoleh dapatan yang sama iaitu amalan Kepemimpinan instruksional pengetua pada keseluruhannya berada di tahap yang tinggi.

Walau bagaimanapun, dapatan kajian ini tidak sejajar dengan kajian oleh Latip (2007), apabila kajian beliau mendapati bahawa tahap pelaksanaan kepemimpinan instruksional pengetua adalah pada tahap yang sederhana. Pernyataan ini disokong lagi oleh Yen dan Abdullah (2017) berkaitan dengan kepimpinan Instruksional memperlihatkan bahawa pengetua berusaha kepada membentuk iklim sekolah yang sihat, ceria dan menyokong usaha guru dan murid dalam proses pengajaran dan pembelajaran. 
Kajian ini mendapati sikap guru terhadap perubahan dalam pendidikan abad ke-21 berada pada tahap tinggi. Indikator ini menunjukkan sikap guru terhadap perubahan dalam pendidikan abad ke-21 dengan berkesan meliputi afektif, kognitif dan tingkah laku. Hal ini demikian kerana pengurusan yang berkesan adalah signifikan terhadap kejayaan operasi sekolah abad ke-21 (Bush, 2011). Tahap sikap guru terhadap perubahan dalam pendidikan abad ke-21 yang berada pada aras tinggi menjadi petunjuk bahawa guru memiliki kemahiran dan keberkesanan dalam melaksanakan perubahan pendidikan dalam abad ke-21.

Namun, kajian ini secara umumnya tidak menyokong kajian Hassan, Rabbani, Shukor Dan Abdul Majid (2018) apabila turut mendapati sikap guru terhadap perubahan dalam kajian mereka berada pada tahap sederhana. Persamaan dapatan juga diperoleh melalui kajian Tai (2017) yang turut mendapati sikap guru terhadap perubahan adalah tidak tinggi. Seterusnya kajian Anghelachea dan Bentea (2012) juga turut mendapati bahawa tahap pelaksanaan sikap guru terhadap perubahan tidak selari dengan kajian ini.

Kajian ini memutuskan bahawa tiada perbezaan dalam kepemimpinan Instruksional pengetua berdasarkan jantina. Keputusan kajian ini menyamai kajian Adi et al., (2002), di mana mereka mendapati bahawa tiada perbezaan persepsi terhadap tingkah laku kepemimpinan instruksional pengetua berdasarkan jantina menunjukkan guru-guru kanan lelaki dan guru-guru kanan perempuan didapati hampir keseluruhanya tidak menunjukkan perbezaan yang signifikan. Hal ini menunjukkan bahawa faktor jantina tidak bias dalam mempersepsikan kepemimpinan instruksional pengetua.

Dalam soal pandangan berkaitan penyelidikan kepemimpinan instruksional terkini kajian Haris (2015), yang bertajuk hubungan kepimpinan instruksional pengetua dengan komitmen kerja dan kepuasan kerja guru di sekolah menengah di daerah Semporna Sabah mendapati bahawa terdapat perbezaan kepimpinan Instruksional berdasarkan jantina. Manakala dalam kajian Andi (2007) dan Latip (2007), mereka mendapati bahawa wujud perbezaan yang signifikan kepemimpinan instruksional pengetua berdasarkan jantina Perbezaan ini mungkin disebabkan oleh responden atau bilangan responden kajian dan lokasi kajian yang berbeza.

Kajian ini mendapati perbezaan skor min yang besar antara guru lelaki dan perempuan dalam sikap guru terhadap perubahan dalam pendidikan abad ke-21. Skor min guru lelaki didapati lebih tinggi berbanding guru perempuan. Hal ini menunjukkan bahawa guru lelaki mempersepsi kan sikap terhadap perubahan dalam pendidikan abad ke-21 lebih baik jika dibandingkan dengan guru perempuan. Walau bagaimanapun, perlu ditegaskan bahawa dapatan kajian ini menunjukkan terdapat perbezaan dari segi skor min. Hal ini bermakna, guru perempuan turut mempersepsi kan sikap guru terhadap perubahan dengan baik dan berkesan.

Perbandingan skor min ini menyamai dapatan beberapa kajian sebelumnya. Antaranya, Vakola dan Nikolaou (2005) mendapati bahawa wanita mendapat skor lebih tinggi dalam hal kesediaan untuk berubah daripada lelaki, dan juga lelaki lebih tahan terhadap perubahan organisasi. Kajian ini ternyata tidak sehaluan dengan dapatan Shah (2014) mendapati bahawa demografi seperti jantina tidak signifikan dalam kajiannya Dapatan kajian selari dengan Jamelaa, (2012) menunjukkan terdapat perbezaan yang signifikan dalam semua dimensi sikap terhadap perubahan berdasarkan jantina. Kajian ini merumuskan bahawa hubungan antara pemboleh-pemboleh ubah bebas dengan pemboleh ubah bersandar adalah signifikan. Walau bagaimanapun, kekuatan hubungan adalah lemah antara kepemimpinan instruksional pengetua dengan sikap guru terhadap perubahan dalam pendidikan abad ke-21.

Secara keseluruhannya, darjah hubungan linear antara kepemimpinan instruksional pengetua dengan sikap guru terhadap perubahan dalam pendidikan abad ke-21 adalah positif. Kepemimpinan instruksional pengetua menjadi satu petanda penting sikap guru terhadap perubahan pendidikan yang diimplementasikan kerajaan. Dapatan kajian yang menunjukkan wujudnya hubungan antara kepemimpinan instruksional pengetua dengan sikap guru terhadap perubahan dalam pendidikan abad ke-21 membuktikan guru mempersepsikan gaya kepemimpinan instruksional seiring dengan sikap guru terhadap perubahan dalam pendidikan abad ke-21. Dapatan ini adalah sejajar dengan beberapa 
kajian terdahulu yang mempunyai penemuan yang sama seperti Mohd Nor Jaafar, (2005), Adil (2014), Izani Ibrahim dan Yahya Don (2014) serta Serin dan Buloc (2012). Dari satu segi, kajian ini tidak menyokong dapatan kajian Lee dan Shukri (2016) dan Gowdy (2015) penemuan kedua-dua kajian tersebut menafikan peranan kepemimpinan instruksional yang dibuktikan mempunyai hubungan dengan sikap guru terhadap perubahan dalam pendidikan abad ke-21.

\section{Implikasi dan Cadangan}

Kajian ini merumuskan bahawa hubungan antara pemboleh ubah bebas dengan pemboleh ubah bersandar adalah signifikan. Kekuatan hubungan adalah lemah yang diperoleh antara pemboleh ubah kepemimpinan instruksional pengetua dengan sikap guru terhadap perubahan dalam pendidikan abad ke-21. Secara keseluruhannya, darjah hubungan linear antara kepemimpinan instruksional pengetua dengan sikap guru terhadap perubahan dalam pendidikan abad ke-21 adalah positif.

Memberi penambahbaikan kepada Model Sikap Terhadap Perubahan Dunham, Grube, Gardener, Cummings dan Pierce (1989). Model asal ATC yang hanya mengandungi 3 konstruk iaitu Afektif, Kognitif Dan Tingkah laku. Penambahbaikan ini diyakini dapat melengkapkan maksud sikap guru terhadap perubahan dalam konteks abad ke- 21 .

Implikasi kajian juga dapat diperhatikan dari segi input tambahan terhadap beberapa teori lain yang mendasari kajian berkaitan sikap guru terhadap perubahan dalam pendidikan abad ke-21. Teori Konsistensi, Teori Pembelajaran Awal, Teori kap, dan Teori Tindakan Bertujuan (TRA) adalah menyokong dapatan kajian yang diperoleh. Selain itu, teori dan model berkaitan kepemimpinan instruksional turut dibuktikan kebergunaan dan implikasinya melalui kajian ini.

Penyelidikan selanjutnya dicadangkan untuk dilaksanakan di sekolah rendah harian biasa bantuan penuh kerajaan atau sekolah di luar kategori ini bagi menguji sama ada hasil dapatan menunjukkan persamaan atau sebaliknya. Akhir sekali, keperluan kajian mengenai impak latihan dan peluang pembangunan profesional dalam kalangan guru adalah mendesak khususnya berkaitan sikap guru terhadap perubahan dalam pendidikan abad ke- 21 .

\section{Kesimpulan}

Berdasarkan penemuan kajian didapati pemboleh ubah bebas iaitu kepemimpinan instruksional pengetua yang dikaji menunjukkan terdapat hubungan dengan sikap guru terhadap perubahan dalam pendidikan abad ke-21. Oleh itu, kepemimpinan instruksional perlu diamalkan pengetua dalam mentadbir organisasinya. Kajian ini merupakan antara penyelidikan terawal yang meneliti hubungan kepemimpinan instruksional pengetua dengan sikap guru terhadap perubahan dalam pendidikan abad ke-21 khususnya di negeri Sabah, Malaysia. Sumbangan kajian ini amat jelas dalam merungkai persoalan-persoalan kajian yang timbul, di samping memberikan ruang atau lompang (gap) untuk kajian seterusnya

\section{Rujukan}

Abdul Aziz, N. A. B. A. (2015). Hubungan Antara Kepimpinan Instruksional Pengetua Dengan Komitmen Untuk Perubahan Guru Sebagai Mediator Dalam Melaksanakan Pentaksiran Berasaskan Sekolah.

Abdul Ghani Abdullah. (2011). Gaya-Gaya Kepimpinan Dalam Pendidikan. Kuala Lumpur: PTS Profesional Publishing Sdn Bhd.]

Abdul Rahman Abdul Majid Khan. (2011). Penyeliaan klinikal dari perspektif pengajaran di sekolah: Panduan sistematik mendiagnosis dan merawat proses pengajaran dan pembelajaran di dalam kelas. Batu Caves, Selangor: PTS 
Adi Fahrudin, Abdul Sani Paijo \& Ahmad Rozelan Yunus. (2002). Tingkah laku kepemimpinan pengajaran pengetua: satu kajian terhadap persepsi guru- guru kanan di beberapa buah sekolah menengah di Kota Kinabalu Sabah. 355 Prosiding Seminar Kebangsaan Profesion Perguruan 2002, hlm. 198- 207.

Adil, M. S. (2014). Impact of Change Readiness on Commitment to Technological Change, Focal, and Discretionary Behaviours: Evidence from The Manufacturing Sector of Karachi. Journal of Organizational Change Management,29(2), 222- 241.

Ahmad, A. R., Salleh, M. J., Awang, M. M., \& Mohamad, N. A. (2013). Investigating Best Practice and Effectiveness of Leadership Wisdom Among Principals of Excellent Secondary School in Malaysia: Perceptions of Senior Assistants. International Education Studies. 6, 38-46.

Ahmad, R., \& Ghavifekr, S. (2014). School Leadership for the 21st Century: A Conceptual Overview. Malaysian Online Journal of Educational Management. 2(1), 48-61.

Ainon Mohd. (2005). Teori dan Teknik Kepimpinan: Panduan Aplikasi di Tempat Kerja.

Ainscow, M., Beresford, J., Harris, A., Hopkins, D., Southworth, G., \& West, M. (2012). Creating the Conditions for School Improvement: A Handbook of Staff Development Activities. New York, NY: Routledge.

Al-Mahdy, Y. F., Al-Harthi, A. S., \& Salah El-Din, N. S. (2016). Perceptions of School Principals' Servant Leadership and Their Teachers' Job Satisfaction in Oman. Leadership and Policy in Schools. 15(4), 543-566.

Amran N. \& Rosli R. (2017). Kefahaman Guru Tentang Kemahiran Abad Ke-21. Universiti Kebangsaan Malaysia.

Andi Audryanah Md. Noor. (2007). Kepemimpinan Pengajaran Dan Efikasi Kendiri Pengetua Sekolah Menengah Dan Hubungannya Dengan Pencapaian Akademik Sekolah. Tesis Sarjana Pendidikan, Johor. Universiti Teknologi Malaysia.

Anghelachea, V., \& Bentea, C. C. (2012). Educational Changes and Teachers' Attitudes Towards

Apak, J., Taat, M. S., Talip, R., \& Kiflee, D. N. A. (2019). Kepimpinan Servan: Satu Alternatif Pengurusan Sekolah Abad Ke-21. Malaysian Journal of Social Sciences and Humanities (MJSSH), 4(3), 173-184.

Aslan, M., Beycioglu, K., \& Konan, N. (2008). Principals' Openness to Change in Malatya, Turkey. International Electronic Journal for Leadership in Learning, 12(8), n8.

Baharom, M. (2004). Persepsi Guru-guru Terhadap Kepimpinan Pengajaran dalam Celik Komputer di Sekolah-Sekolah di Negeri Johor. (Tesis Doktor Falsafah yang tidak diterbitkan). Universiti Kebangsaan Malaysia, Selangor.

Bai, N., Piri, R. \& Piri, A. (2014). Investigating school organizational climate and job satisfaction from Kalale physical education teachers' point of view. Research Journal of Sport Science, 2(2), 45-49.

Bareil, C., Savoie, A., \& Meunier, S. (2007). Patterns of discomfort with organizational change. Journal of Change Management, 7(1), 13-24.

Bernerth, J. (2004). Expanding our understanding of the change message. Human resource development review, 3(1), 36-52.

Eby, L. T., Adams, D. M., Russell, J. E., \& Gaby, S. H. (2000). Perceptions of organizational readiness for change: Factors related to employees' reactions. to the implementation of teambased selling. Human relations, 53(3), 419-442.

Fullan, M. (2011). The six secrets of change: What the best leaders do to help their organizations survive and thrive. John Wiley \& Sons.

Hassan, M.A.A., Rabbani, M.F., Shukor, M.E.M. and Majid, M.M.A., (2018). Sikap Guru Terhadap Perubahan dalam Sekolah di Malaysia. Management Research Journal, 7, 188-196.

Ibrahim, I., \& Don, Y. (2014). Kepimpinan Servant dan Pengaruhnya terhadap Pengurusan Perubahan di Sekolah (Servant Leadership and Influence on Changes Management in Schools). Jurnal Pendidikan Malaysia (Malaysian Journal of Education), 39(1), 19-26.

Jainabee, M. K., \& Jamelaa, B. A. (2011). Promoting Learning Environment and Attitude towards Change among Secondary School Principals in Pahang Malaysia: Teachers' Perceptions. Procedia Social and Behavioural Sciences, 28(2011), 45-49.

Lee dan Shukri. (2016). Pengaruh Kepimpinan Instruksional, Efikasi dan Tugas Rutin Pengetua Terhadap Pencapaian Akademik. Malaysian Journal of Social Sciences and Humanities, 1(3), 4265. 